\title{
The bread making quality of Finnish spring wheats - a proposal for classification
}

\author{
JARI PELtONEN, TAPIO JUUTI and JUHA SALOPELto
}

\begin{abstract}
Peltonen, J., Juuti, T. \& Salopelto, J. 1993. The bread making quality of Finnish spring wheats - a proposal for classification. Agric. Sci. Finl. 2: 507-515. (Department of Plant Production, FIN-00014 University of Helsinki, Finland and Anttila Plant Breeding Farm, FIN-04300 Tuusula, Finland.)

The purpose of the present study was to provide bread making quality criteria for spring wheat (Triticum aestivum L.) grown in Finland. The bread making quality of a total of 101 wheat samples was related to flour protein concentration and dough quality determined by the farinograph valorimeter value. Nine quality classes of wheat, similar to the German system of wheat classification, were used as a basis. Because Finnish wheat breeding and cultivation primarily aim at producing grain for bread making, it was not considered necessary to define the quality classes of wheat unsuitable for bread making. Therefore, the number of quality classes were restricted to five: (class 1) medium, (class 2 ) medium to high, (class 3 ) high, (class 4 ) high to very high, and (class 5) very high baking quality. The influence of the environment on the quality traits should be taken into account by comparing the cultivars with a representative control cultivar.
\end{abstract}

Key words: spring wheat, bread-making quality criteria, quality classes

\section{Introduction}

The baking quality of wheat is dependent on both genetic and environmental factors. By selecting wheat cultivars with an optimal high molecular weight glutenin subunit composition the bread making properties can be improved (PELTONEN et al. 1993). However, a genetically good quality wheat cultivar can be of poor industrial quality if environmental conditions and management practises are not proper (SAlOVAARA 1986a, PELTONEN 1992). However, before the industrial baking quality of wheat cultivars grown in different environments can be estimated, wheats should be divided into classes on the basis of their end-use. One approach would be to distinguish the weakness or incompleteness of the flour material and to exclude materials not meeting the required standards or specifications. Another approach would be to have a certain number of quality classes according to the type of bread and baking processes used. For example, the American Soft Red (SR) and Soft White (SW) wheat types are intended for baking cakes and biscuits. The quality of Durum wheat is suitable for semolina and pasta production, whereas Hard Red Winter (HRW) and Hard Red Spring (HRS) wheats are suitable for bread making.

In Finland there is no well defined quality classification system of Finnish wheat cultivars available. Regarding industrial French breadmaking from spring wheat in Finland, the relationships between analytical quality tests on a laboratory scale and performance in industrial baking processes have been studied (SALOVAARA 1986b). In addi- 
tion, some requirements of good quality wheat flour such as protein and gluten content, and dough quality have been suggested (KULHOMÄKI and SALOVAARA 1985, LAUKKANEN 1991). A classification system based on an index of 22 quality parameters (including grain, flour, dough and bread property parameters) has been suggested (HUTTUNEN et al. 1980). It is, however, complicated to determine what to emphasize in each quality parameter to form such an index. On the other hand, quality classification of Finnish wheats based on quality parameters that can describe the requirements of wheat flour to be used for the Finnish type of bread and for the bread-making processes used in Finland will be of advantage both for the breeding work and for the industrial management of the wheat crop. The variation in quality due to environmental factors can be taken into account by use of a wellknown control cultivar (PELTONEN 1992).

This study was carried out to determine bread making quality criteria for classification of wheat cultivars into quality classes. The proposed classification system of wheat is based on the German wheat quality classes (Weizensorten und Backqualität 1990). In that classification system variation in quality caused by the environment is estimated by using the spring wheat cultivar 'Turbo' as control. The wheat cultivars are divided into nine quality classes according to their bread volumes in comparison to the control cultivar. The control cultivar represents medium to high baking quality.

\section{Material and methods}

\section{Field trials}

The spring wheat (Triticum aestivum L.) samples were grown in field trials at Hankkija Plant Breeding Institute (present address: Anttila Experimental Farm) during $1980-83$ and 1985-89. The 101 samples of spring wheats consisted of commercial cultivars 'Ulla' (grown in 1980-86), 'Heta' (198288), 'Ruso' (1980-1989), 'Taava' (1980), 'Tapio' (1980-1986), 'Kadett' (1985 and 1989), 'Drabant' (1980 and 1982), 'Tähti' (1980-82), and 92 pure and homozygous breeding lines. The breeding lines were based on crosses of Scandinavian wheat cultivars. The field experiments included four replicates, and the plot size was $8 \mathrm{~m}^{2}$. Nitrogen fertilization, $110 \mathrm{~kg} \mathrm{~N} \mathrm{ha}^{-1}$, was applied in a granular form of ammonium nitrate.

\section{Quality evaluation}

Replicated yield samples were harvested at the caryopsis hard stage. Grain samples were pooled and mixed thoroughly for quality analyses. The following quality parameters were determined: flour protein concentration (\%, FPC) by the method 46-11 (AACC 1985), wet gluten content (\%, WGLUT) of flour and Zeleny sedimentation volume (ml, ZEL) using standards 137 of the ICC (1982) and 116 of the ICC (1972), respectively, dough water absorption (\%, FABS) by the method 54-21 of the AACC (1982), and the Brabender Farinograph valorimeter value (FVALO) by the method 54-21 of the AACC (1982). FVALO is an empirical single-figure quality score based on dough development time and tolerance to mixing derived from farinogram by means of a special template supplied by the manufacturer of the farinograph equipment. Dough stretching characteristics were determined with the Brabender Extensograph (standard 114, ICC 1972). Dough extensibility (EXT) as resistance ratio of maximum resistance to extensibility was calculated according to Fullington et al. (1987) to describe dough stretching with a single-figure.

Test baking was made from $250 \mathrm{~g}$ of flour according to the long fermentation process (HUTTUNEN et al. 1980). Dough with optimum water absorption (\%) was mixed for 5 minutes in a farinograph mixing bowl. The dough was allowed to pre-ferment for 90 minutes at room temperature $\left(20^{\circ} \mathrm{C}\right)$. Remoulding of dough was done twice after 45 minutes of pre-fermentation. After pre-fermentation, the dough was allowed to rise in a baking pan for 90 minutes in a fermentation cabinet at $80 \%$ relative humidity and $32^{\circ} \mathrm{C}$. The final baking was done in a laboratory oven at $230^{\circ} \mathrm{C}$ and the baking time was about 20 minutes. The loaf volume $(\mathrm{ml}$, 
LV) was measured on the baking day by the rape seed displacement method. The loaves were left overnight at room temperature before subjective crumb texture assessment. Loaf resilience (LR) was measured from a piece of loaf $(5.0 \times 5.0 \times 5.0 \mathrm{~cm})$ by depressing the loaf texture $3.0 \mathrm{~cm}$ with a lead cube ( $1 \mathrm{~kg}$ ) during 5 seconds. Five seconds after the lead cube was released the reversion of loaf texture was measured in centimeters. The reversion was determined using a scoring system of $0-10$ (poor to good) as follows:

$\begin{array}{cc}\text { Reversion cm } & \text { Loaf resilience (LR) } \\ 2.0 & 0 \\ 2.1-2.3 & 0.5-1.0 \\ 2.4-2.6 & 1.5-2.0 \\ 2.7-2.9 & 2.5-3.0 \\ 3.0-3.2 & 3.5-4.0 \\ 3.3-3.5 & 4.5-5.0 \\ 3.6-3.8 & 5.5-6.0 \\ 3.9-4.1 & 6.5-7.0 \\ 4.2-4.4 & 7.5-8.0 \\ 4.5-4.7 & 8.5-9.0 \\ 4.8-5.0 & 9.5-10.0\end{array}$

The scores for loaf overall appearance (LAPP) were determined using the following equations:

$\mathrm{LAPP}=$ volume factor $\mathrm{x}$ symmetry of crumb texture

where volume factors correspond the volume yield as follows:

Volume factor

Volume yield
300
350
400
430
500

Volume yield was measured as follows:

volume yield $=$ loaf volume $\mathrm{x}$ dough yield (dry weight basis) : dough weight

Symmetry of crumb texture was determined by the pore size using a scoring system of 1-8 (small to large) described by a simple factor of symmetry of crumb texture (0.3-1.0) as follows:

$\begin{array}{lc}\text { Pore size } & \text { Symmetry of crumb texture } \\ 1 & 0.3 \\ 2 & 0.4 \\ 3 & 0.5 \\ 4 & 0.6 \\ 5 & 0.7 \\ 6 & 0.8 \\ 7 & 0.9 \\ 8 & 1.0\end{array}$

All the quality analyses and baking tests were done at the Grain Research Laboratory of the State Granary, Helsinki.

\section{Classification of wheat cultivars}

The German classification system of wheat quality (Weizensorten und Backqualität 1990) was applied to classify the quality of Finnish spring wheat cultivars. The German system separates wheat varieties into nine different classes according to a control cultivar. The quality of the control cultivar was based on loaf volume and it was assigned to class 6 (Table 1). In the present study, cultivar 'Ruso' was used as a control, because it was the only cultivar which was grown during the whole study period. The cultivar 'Ruso' was used as a control also in the state official experiments during the study period (MUSTONEN et al. 1986). Each season the quality properties were compared to the control cultivar 'Ruso' ( $Q_{i} / Q_{c} \times 100$, where $Q_{i}$ is the actual quality property of a cultivar or breeding line and $\mathrm{Q}_{c}$ is the quality property of the control cultivar). One way analysis of variance (ANOVA) and the MSTAT 4.0 (MSTAT 1989) program were used to calculate the mean values of the quality properties for each class. The values obtained were coded with numbers from 1 to 9 to indicate which Finnish quality class corresponds to the German quality class (Table 1). Simple correlations between quality parameters were computed using linear regression analysis.

The proposed quality classes were tested against wheat cultivars 'Apu', 'Benito', 'Heta', 'Kadett', 'Katepwa', 'Luja', 'Polkka', 'Reno', 'Runar', 'Ruso', 'Satu', 'Tapio', and 'Tähti', grown at Hankkija Plant Breeding Institute during 1989-90. 
Table 1. German quality classes for wheat based on loaf volume. Comparison has been made to a control cultivar (Weizensorten und Backqualităt 1990).

\begin{tabular}{llc}
\hline $\begin{array}{l}\text { Quality } \\
\text { Class }\end{array}$ & Baking quality & $\begin{array}{c}\text { Range of quality" } \\
\text { classes (\%) }\end{array}$ \\
\hline 1 & Very low & $<75.6$ \\
2 & Very low to low & $75.6-80.5$ \\
3 & Low & $80.6-85.5$ \\
4 & Low to medium & $85.6-90.5$ \\
5 & Medium & $90.6-95.5$ \\
6 & Medium to high (Control) & $95.6-100.5$ \\
7 & High & $100.6-105.5$ \\
8 & High to very high & $105.6-110.5$ \\
9 & Very high & $>110.5$ \\
\hline
\end{tabular}

" Range of quality classes taken from the German system.

The same quality parameters and the same methods were used as described earlier.

\section{Results}

All the spring wheats tested in this study showed a high degree of variation $(\mathrm{P}<0.001)$ in quality properties between genotypes and growing seasons (Table 2). The simple correlations between the quality parameters (Table 3 ) showed that LV correl-
Table 2. Quality traits of spring wheat grown at Hankkija Plant Breeding Institute in 1980-83 and 1985-1989.

\begin{tabular}{lcccr}
\hline $\begin{array}{l}\text { Quality } \\
\text { Trait }\end{array}$ & Minimum & Maximum & Mean & $\begin{array}{r}\text { Standard } \\
\text { Deviation }\end{array}$ \\
\hline PROT & 9.5 & 17.8 & 12.7 & 1.50 \\
WGLUT & 20.5 & 49.4 & 29.0 & 5.65 \\
ZEL & 15.0 & 74.0 & 56.6 & 15.14 \\
FABS & 52.0 & 64.0 & 56.1 & 2.32 \\
FVALO & 20.0 & 98.0 & 51.3 & 11.76 \\
EXT & 0.66 & 1.58 & 1.08 & 0.20 \\
LV & 1220.0 & 1860.0 & 1544.3 & 125.97 \\
LR & 3.0 & 10.0 & 7.13 & 1.90 \\
LAPP & 378.0 & 747.0 & 579.3 & 77.61 \\
\hline
\end{tabular}

Abbreviations: FPC flour protein concentration $(\%)$, WGLUT wet gluten content (\%), ZEL Zeleny sedimentation volume (ml), FABS Farinograph dough water absorption (\%), FVALO Farinograph valorimeter value, EXT Extensograph dough extensibility, LV loaf volume ( $\mathrm{ml})$, LR loaf resilience, LR loaf overall appearance.

ated positively with LAPP ( $\mathrm{r}=0.72)$. An increase in FPC also increased FVALO ( $r=0.67)$. The moderate correlation between ZEL and LV was positively significant $(\mathrm{r}=0.58)$. Other significant correlations between FPC-WGLUT, FPC-ZEL, FPC-LV, WGLUTZEL, WGLUT-FVALO, WGLUT-LV, WGLUT-LAPP, ZEL-EXT, ZEL-LR, ZEL-LAPP, FABS-EXT, EXT-LR, LV-LR and LR-LAPP were

Table 3. Significant phenotypic correlations between quality characteristics.

\begin{tabular}{|c|c|c|c|c|c|c|c|c|c|}
\hline $\begin{array}{l}\text { Quality } \\
\text { Trait }\end{array}$ & 1. & 2. & 3. & 4. & 5. & 6. & 7. & 8. & 9. \\
\hline
\end{tabular}

1. FPC 1

2. WGLUT $0.51^{* * *} 1$

3. ZEL $0.44 * * * 0.49 * * * 1$

4. FABS -

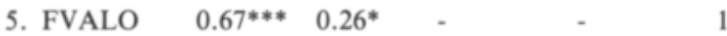

6. EXT - $\quad-0.32^{*}-0.30^{*}-1$

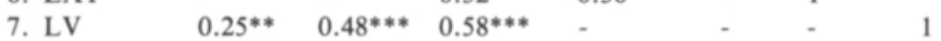

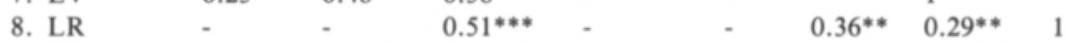

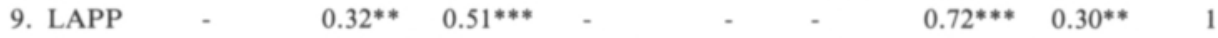

Abbreviations: FPC flour protein concentration (\%), WGLUT wet gluten content (\%), ZEL Zeleny sedimentation volume $(\mathrm{ml})$, FABS Farinograph dough water absorption $(\%)$, FVALO Farinograph valorimeter value, EXT Extensigraph dough extensibility, LV loaf volume (ml), LR loaf resilience, LAPP loaf overall appearance.

$*, * *, * * *$ Significant at $\mathrm{P}=0.05,0.01,0.001$, respectively. 
Table 4. Proposal for quality classes based on flour protein concentration (FPC), Zeleny sedimentation volume (ZEL), farinograph valorimeter value (FVALO), loaf volume (LV), and scores of overall appearance of loaf (LAPP). Ruso = Control.

\begin{tabular}{|c|c|c|c|c|c|c|c|c|c|}
\hline Quality class* & 1 & 2 & 3 & 4 & 5 & 6 & 7 & 8 & 9 \\
\hline Range $(\%)$ & $<75.6$ & $75.6-80.5$ & $80.6-85.5$ & $85.6-90.5$ & $90.6-95.5$ & $95.6-100.5$ & $100.6-105.5$ & $105.6-110.5$ & $>110.5$ \\
\hline FPC (mean) & $<9.1$ & $9.1-9.7$ & $9.8-10.3$ & $10.4-10.9$ & $11.0-11.5$ & $11.6-12.0$ & $12.1-12.7$ & $12.8-13.3$ & $>13.3$ \\
\hline Ruso $=100$ & & & & & & 12.0 & & & \\
\hline $\mathrm{n}$ & - & - & - & - & 6 & 21 & 16 & 20 & 37 \\
\hline ZEL (mean) & $<32.3$ & $32.3-34.4$ & $34.5-36.5$ & $36.6-38.6$ & $38.7-40.8$ & $40.9-44.9$ & $43.0-45.0$ & $45.1-47.2$ & $>47.2$ \\
\hline Ruso $=100$ & & & & & & 42.7 & & & \\
\hline $\mathrm{n}$ & - & - & - & - & 3 & 8 & 4 & 5 & 53 \\
\hline FVALO (mean) & $<38.6$ & $38.6-41.1$ & $41.2-43.6$ & $43.7-46.2$ & $46.3-48.7$ & $48.8-51.3$ & $51.4-53.8$ & $53.9-56.4$ & $>56.4$ \\
\hline Ruso $=100$ & & & & & & 51 & & & \\
\hline $\mathrm{n}$ & 4 & 3 & 2 & 5 & 5 & 14 & 5 & 4 & 42 \\
\hline LV (mean) & $<1138$ & $1138-1212$ & $1213-1287$ & $1288-1362$ & $1363-1437$ & $1438-1513$ & $1514-1588$ & $1589-1663$ & $>1663$ \\
\hline Ruso $=100$ & & & & & & 1505 & & & \\
\hline $\mathrm{n}$ & - & - & - & 4 & 7 & 36 & 25 & 16 & 12 \\
\hline LAPP (mean) & $<415.8$ & $415.8-442.8$ & $442.9-470.3$ & $470.4-497.8$ & $497.9-525.3$ & $525.4-552.8$ & $552.9-580.3$ & $580.4-607.8$ & $>607.8$ \\
\hline Ruso $=100$ & & & & & & 550 & & & \\
\hline $\mathrm{n}$ & 3 & 1 & 4 & 7 & 13 & 6 & 9 & 20 & 37 \\
\hline
\end{tabular}

* cf. Table 1.

recorded, but the correlation coefficients were weak. Therefore, for further analysis, we concentrated on FPC, ZEL, FVALO, LV, and LAPP values in order to provide a classification system.

The FPC, ZEL, FVALO, LV and LAPP values were classified in comparison to the control cultivar 'Ruso' (Table 4) using the ranges (from $<75.6$ to $>110.5$ ) of quality classes (1-9) described in Table 1. ANOVA was used to form the corresponding range for each class from the means of the quality parameters. The classification of wheats according to FPC indicated that in class 6 (medium to high baking quality), the corresponding FPC values varied from 11.6 to $12.0 \%$ (Table 4). The limit for class 9 (very high quality) was determined by the FPC value $13.3 \%$. LAUKKANEN (1991) pointed out that a protein concentration of $13 \%$ would be optimal for the industrial uses in Finland. All wheats represented at least medium baking quality (class 5) when compared with the control cultivar 'Ruso'.

The classification based on ZEL showed that the range of ZEL values in class 6 is $40.9-44.9 \mathrm{ml}$. According to LAUKKANEN (1991) a ZEL value of 30 would be optimal for the industrial uses in Fin- land. The lowest ZEL values in this study were above $38 \mathrm{ml}$, indicating medium baking quality (class 5). More frequently the ZEL values fell into class 9 .

The classification based on FVALO showed that the limit of very low baking quality (class 1) was 38.6. The range of FVALO values was 48.8 - 51.3 in class 6 (medium to high quality). An FVALO value above 56.4 indicated a class 9 category.

According to $\mathrm{LV}$ values, the baking quality varied from class 4 to class 9 . On average, the baking quality classified according to $\mathrm{LV}$ indicated classes 6 and 7. In class $6, \mathrm{LV}$ values varied from 1438 to $1513 \mathrm{ml}$. A LV value above $1663 \mathrm{ml}$ indicated very high quality (class 9).

The LAPP values divided the quality into all nine classes, although a great deal of the LAPP belonged to classes 8 and 9. LAPP over 607.8 was an indicator of very high baking quality, a LAPP score less than 415.8 being a characteristic of class 1 (very low baking quality).

The correlation coefficients were calculated between the means of FPC, ZEL, FVALO, LV and LAPP presented in 9 quality classes (Table 4) to 
Table 5. Significant correlations between qualities proposed in Table 4.

\begin{tabular}{llllll}
\hline Quality & 1. & 2. & 3. & 4. & 5. \\
Trait & & & & & \\
\hline
\end{tabular}

1. FPC 1

2. ZEL $0.42^{* * *} 1$

3. FVALO $0.55^{* * *} 0.34^{* *} \quad 1$

4. LV $0.35^{*}-0.26{ }^{*}$

5. LAPP $0.23^{*} \quad-\quad 0.40^{* * *} 0.25^{*} 1$

Abbreviations: FPC flour protein concentration (\%), ZEL Zeleny sedimentation volume $(\mathrm{ml})$, FVALO Farinograph valorimeter value, $\mathrm{LV}$ loaf volume $(\mathrm{ml})$, LAPP loaf overall appearance.

${ }^{*},{ }^{* *},{ }^{* * *}$ Significant at $\mathrm{P}=0.05,0.01,0.001$, respectively.

demonstrate their dependence on each other (Table $5)$. The strongest correlation was found between FPC and FVALO ( $r=0.55)$. The other correlations were poor $(\mathrm{r} \leq 0.42)$. Therefore, classifications based on FPC and FVALO were tested against 13 independent wheat cultivars grown during 198990 , and their mean values were calculated (Table 6). Our results showed that cultivars 'Benito' and 'Katepwa' - both HRS wheat types - were categorised into class 9 (very high baking quality) as compared with control cultivar 'Ruso' (class 6). HRS wheat types are commonly imported to compensate for the poor quality of domestic grain. Cultivars 'Heta', 'Satu' and 'Tähti' showed high to very high baking quality (class 8 ), and 'Polkka' high quality (class 7). Medium to high baking quality (Class 6) included control cultivar 'Ruso' and cultivars 'Apu', 'Reno', and 'Runar', while cultivars 'Kadett', 'Tapio' and 'Luja' belonged clearly to the lowest class (class $5=$ medium quality). These results confirmed the earlier reports on the baking quality of these wheat cultivars in industrial baking (SALOVAARA 1986a), in breeding programmes (JUUTI 1988), and in commercial wheat production (HUTTUNEN and LILJA 1990).

\section{Discussion}

The evaluation of Finnish spring wheat cultivars indicated that the bread making quality could be
Table 6. Division of spring wheat cultivars grown in 1989-90 at Hankkija Plant Breeding Institute into quality classes according to flour protein concentration (FPC) and farinograph valorimetric value (FVALO).

\begin{tabular}{|c|c|c|c|}
\hline \multirow[t]{2}{*}{ Cultivar } & \multicolumn{2}{|c|}{ Proposed quality class } & \multirow{2}{*}{$\begin{array}{c}\text { Quality } \\
\text { Class } \\
\text { (Mean) }\end{array}$} \\
\hline & FPC & FVALO & \\
\hline Benito $(\mathrm{AC})^{*}$ ) & 9 & 9 & 9.0 \\
\hline Katepwa (AC) & 9 & 9 & 9.0 \\
\hline Heta $(\mathrm{Hja})$ & 9 & 7 & 8.0 \\
\hline Satu (WW) & 8 & 8 & 8.0 \\
\hline Tähti (Jo) & 7 & 9 & 8.0 \\
\hline Polkka (Sv) & 7 & 8 & 7.5 \\
\hline Apu (Jo) & 8 & 5 & 6.5 \\
\hline Reno (NLH) & 6 & 7 & 6.5 \\
\hline Runar (NLH) & 6 & 6 & 6.0 \\
\hline Ruso ( $\mathrm{Hja}$, control) & 6 & 6 & 6.0 \\
\hline Kadett (WW) & 5 & 6 & 5.5 \\
\hline Tapio (Hja) & 6 & 5 & 5.5 \\
\hline Luja (Jo) & 7 & 3 & 5.0 \\
\hline
\end{tabular}

*) Breeder: $\mathrm{AC}=$ Canada; $\mathrm{Hja}=$ Hankkija (Finland); Jo $=$ Jokioinen (Finland); WW = Weibull (Sweden); $\mathrm{Sv}=$ Svalöf (Sweden); NLH = Department of Crop Science, NLH Norway

described by the flour protein concentration (FPC) and the farinograph valorimeter value (FVALO). Our results are in agreement with BAKER et al. (1971) and FOWLER and de la ROCHE (1975) who concluded that FPC in addition to farinograph dough quality were effective indicators of baking quality, thus replacing baking tests in quality breeding. VARIS and JUUTI (1975) showed that both farinograph dough quality and bread volume were improved by $\mathrm{N}$ fertilization strategies, raising the protein concentration in winter wheats. SALOVAARA (1986b) reported that farinograph dough quality and wet gluten content were the best indicators of industrial French bread making quality of spring wheat. However, our results indicated that wet gluten content (WGLUT) correlated poorly (Table 3) with FPC, dough quality (FABS, FVALO, EXT) and loaf quality (LV, LR, LAPP) parameters. In the present situation in Finland, FPC would be more a suitable indicator of quality than WGLUT. The pricing system of wheat, too, is based on protein concentration, in addition to starch quality and test weight (Viljaliite 1992). It is recom- 
mended to combine both FPC and FVALO in the pricing system in order to give a better understanding of the quality of flour. This is mainly due to high protein concentration not necessarily being linked to high dough quality. PELTONEN et al. (1993) have indicated that farinographic data describes well the quality of gluten of the cultivars which have different combinations of high molecular weight glutenin subunits. Thus, to optimize the system, FVALO should be included to contribute information also about genetic factors such as gluten composition.

The correlation between loaf volume and the other quality traits in the classes proposed was low (Table 5). This may indicate that the test baking procedure used in Finland (HUTTUNEN et al. 1980) is not suitable for predicting the bread-making quality of flour for the particular type of bread and the baking processes used by the Finnish bakeries. In a Swedish wheat breeding programme, the bread making potential of cultivars is tested at two different dough mixing intensities before release, thus indicating the suitability of a cultivar for different bread making processes (SVENSSON 1987). In future, it would be important to focus on the different test baking procedures in relation to industrial baking performance. In Finland, optimizing the mixing time instead of using constant mixing for 5 minutes may give improvements. It could then be possible to provide quality classes for wheat based on loaf volume only, as does the German classification system (Weizensorten und Backqualität 1990).

Because wheat breeding and cultivation in Finland primarily aim at producing grain for bread making (KIVI 1969), quality classes lower than medium baking quality (classes 1-4, Table 1) are not
Table 7. Proposal for qualty classes in Finland based on flour protein concentration (FPC) and farinograph valorimetric value (FVALO).

\begin{tabular}{lcc}
\hline Quality class and baking quality & $\begin{array}{c}\text { FPC } \\
\text { (range) }\end{array}$ & $\begin{array}{c}\text { FVALO } \\
\text { (range) }\end{array}$ \\
\hline 1 Medium & $<11.5$ & $<48.7$ \\
2 Medium to high (control) & $11.6-12.0$ & $48.8-51.3$ \\
3 High & $12.1-12.7$ & $51.4-53.8$ \\
4 High to very high & $12.8-13.3$ & $53.9-56.4$ \\
5 Very high & $>13.3$ & $<56.4$ \\
\hline
\end{tabular}

necessarily required. Therefore, we suggest that the classification system of wheat in Finland should contain five classes. This idea is also supported by the results in Table 6, whereby the commercial Finnish wheat cultivars were divided into five classes. Quality classes and the corresponding range in FPC and FVALO values of the recommended classification system are given in Table 7 . Wheat of the highest quality classes (classes 4 and 5) with strong gluten could be used to compensate for the baking quality of wheats in class 1 . In turn, wheats in classes 2 and 3 could be used directly for bread making. The class ranges presented in Table 7 are depended on the control cultivar used. Obviously, the cultivar 'Ruso' is now too old (released in 1967) to be used as a control. Later released cultivars are of better bread-making quality than 'Ruso' (Table 6). Therefore, another control cultivar than 'Ruso' should be chosen in the future.

Acknowledgements. The constructive and critical discussions during the preparation of the manuscript offered by Prof. Erkki Kivi and Dr. S. Mohan Jain are acknowledged.

\section{References}

AACC 1982. Approved methods of the AACC. American Association of Cereal Chemists, St. Paul, MN.

- 1985. Approved methods of the AACC. American Association of Cereal Chemists, St. Paul, MN.

Baker, R.J., Tipples, K.H. \& CAmpBel., A.B. 1971. Heritabilities of and correlations among quality traits in wheat. Can. J. Plant Sci. 51: 441-448.

Fowler, D.B. \& Roche, I.A. de la 1975. Wheat quality evaluation. 2. Relationships among prediction tests. Can. J. Plant Sci. 55: 251262.

Fullington, J.G., Miskelly, D.M., Wrigley, C. W. \& KASARDA, D.D. 1987. Quality-related endosperm proteins in sulphurdeficient and normal wheat grain. J. Cereal Sci. 5: 233-245.

Huttunen, R., Korkman, M., Koskinen, K. \& LALluKKa, U. 1980. Vehnän laadun arvostelu. Menetelmăn kehittelyă. 
Viljantutkimustoimikunta ja Valtion Viljavarasto Tutkimuslaboratorio. Tiedonantoja 6/80.32 p.

— \& LILJA, S. 1990. Vehnän leivontalaatu: viljaotantanäytteet 1985-1987, viralliset lajikekoenäytteet 1985-1986. Valtion Viljavaraston Viljalaboratorio. Tiedonantoja 1/90. 34 p.

ICC 1972. Standard methods of the ICC. International Association for Cereal Chemistry, Vienna. Verlag Moritz Schfer, Detmold, Germany.

- 1982. Standard methods of the ICC. International Association for Cereal Chemistry, Vienna. Verlag Moritz Schfer, Detmold, Germany.

JuUTı, T. 1988. Heta-kevătvehnä. Hankkijan kasvinjalostuslaitos. Tiedote 33. 21 p.

Kıvı, E. 1969. Sadon käyttöarvo kevätvehnänjalostuksen tavoitteena. Summary: Quality properties in the Finnish spring wheat breeding. Ann. Agric. Fenn. 8: 193-204.

KulhomÄKı, S. \& SAlOVAARA, H. 1985. Laatuleipää käsikirja leipurille. Leipomoalan Edistämissäätiö. Helsingin yliopisto, Elintarvikekemian ja -teknologian laitos. EKT-sarja 706.84 p.

LAUKKANEN, T. 1991. Vehnän laatuvaatimukset. Melia Viljalaboratorio. 9.8.1991. $1 \mathrm{p}$.

MSTAT 1989. MSTAT User's Guide: A microcomputer program for the design, management, and analysis of agronomic research experiments. MSTAT Development Team. Michigan State Univ., East Lansing.

Mustonen, L., Pulli, S., Rantanen, O. \& Mattila, L. 1986. Virallisten lajikekokeiden tuloksia 1978-1985. Maatalouden tutkimuskeskus. Tiedote 5/86. 128 p.

Peltonen, J. 1992. Influence of environment and genotype on spring wheat yield and bread-making quality under Finnish conditions. Acta Agric. Scand. 42: 111-117.

-, Salopelto, J. \& Rita, H. 1993. The optimal combination of HMW glutenin subunits coded at gene loci Glu-Al and Glu-BI for bread-making quality in Scandinavian wheats. Hereditas 118: 71-78.

SalovaAra, H. 1986a. Experiences of testing wheat cultivars in industrial baking. Acta Agric. Scand. 36: 225-239.

- 1986b. Wheat and flour quality related to baking performance in industrial French bread processes. Acta Agric. Scand. 36: 387-398.

Svensson, G. 1987. The importance of test baking in wheat breeding. Cereal Sci. Technol., DCS. 23. Nordig Cereal Cong. Copenhagen. p. 273-281.

V ARIS, E. \& JUUTI, T. 1975. Syysvehnän typpilannoituksen ajoittamisesta. Summary: Timing of nitrogen application in winter wheat production. J. Sci. Agric. Soc. Finl. 47: 270-282.

Viljaliite 1992. Maaseudun Tulevaisuus. 15.8.1992. 12 p.

Weizensorten und Backqualität 1990. Beschreibe Sorteliste für Getreide, Mais, Ölfrüchte, Leguminosen (Grosskörnig), Hackfrüchte (ausser Kartoffeln). Herausgegeben vom Bundessortenamt, Hannover, Germany, p. 80-93.

\section{Manuscript received May 1993}

Jari Peltonen

Department of Plant Production

P.O. Box 27 (Viikki)

FIN-00014 University of Helsinki, Finland

Tapio Juuti

Juha Salopelto

Anttila Plant Breeding Farm

FIN-04300 Tuusula, Finland 


\title{
SELOSTUS
}

\section{Kotimaisen kevätvehnän leivontalaadun luokitusehdotus}

\author{
Jari Peltonen, Tapio JuUti ja Juha Salopelto
}

Helsingin yliopisto ja Anttilan kasvinjalostuslaitos

Tămăn tutkimuksen tarkoituksena oli luoda ehdotus vehnän laadun luokittamiseksi koska Suomessa ei vielă ole kotimaisen vehnän laadun selkeảä, käyttötarkoitukseen perustuvaa luokitusta. Perustaksi valittiin vehnän saksalainen laatuluokitusmalli. Tutkimusaineistona olivat Hankkijan kasvinjalostuslaitoksen päăkokeissa, Tuusulassa vuosina 1980-83 ja $1985-89$ viljellyt kevätvehnät.

Saksalaisen mallin mukainen luokitus ja regressioanalyysi osoittivat jauhojen valkuaispitoisuuden ja farinografilla mitatun taikinan laadun (valorimetriluku) olevan parhaat ominaisuudet leivontalaadun luokitusta varten. Vehnää viljellään maassamme yksinomaan leipävehnăksi, joten alhaista leivontalaatua kuvaavia luokkia ei todennăköisesti tarvita. Tämän vuoksi ehdotamme jakoa viiteen laatuluokkaan. Korkeimpia laatuluokkia edustaisivat laatuluokat neljä ja viisi. Näiden luokkien vehnäjauhot soveltuisivat parhaiten vahvennusvehnăksi parantamaan keskitasoisen (luokka 1) tai sitä heikompien vehnien leivontalaatua. Keskitasoista - korkeaa leivontalaatua olisi mittarilajikkeen edustama laatuluokka (luokka 2), joka yhdessä laatuluokan 3 kanssa soveltuisi jauhatukseen sellaisenaan.

Luokituksen luokkarajat ovat kuitenkin riippuvaisia käytetystä mittarilajikkeesta. Ruso-kevätvehnä on mittarilajikkeeksi ilmeisesti vanha (laskettu kauppaan 1967), sillä Ruso mittarilajikkeena muu tutkimusaineisto jakaantui suurelta osin erittäin korkeaa laatua kuvaaviin luokkiin. Mikäli vehnän laatuluokkajärjestelmän toteuttaminen todetaan tulevaisuudessa aiheelliseksi, tulisi valita uusi edustava mittarilajike vastaamaan laadunjalostuksen nykyistä tasoa. 